\title{
Analysis of the use of selection achievements in the production of oilseeds
}

\author{
Dmitry Buklagin ${ }^{1, *}$ \\ ${ }^{1}$ Federal State Budgetary Scientific Institution «Russian Research Institute of Information and \\ Technical and Economic Studies on Engineering and Technical Provision of Agro-Industrial \\ Complex», 60, st. Lesnaya, 141261, Pravdinsky, Pushkin district, Moscow region, Russia
}

\begin{abstract}
The availability of spare capacities for the production of vegetable oil in Russia and the increased demand in the world's industrial markets stimulate the development of domestic competitive technologies for growing, storing and processing sunflower, soybean and rapeseed. Reducing the level of dependence of oilseeds on foreign analogues is considered as one of the key tasks. Currently, the share of foreign varieties in Russia occupies about $56 \%$ of the acreage of spring rapeseed, $76 \%$ of winter rapeseed, $74 \%$ of sunflower and $26 \%$ of soy. It is shown that the inclusion of foreign varieties of oilseeds in the State register of varieties approved for use in the Russian Federation is not always justified. It is recommended to include in the state register only those varieties of foreign selection that have a statistically significant difference in the indicators of domestic and foreign varieties obtained as a result of their tests in the regions of Russia.
\end{abstract}

\section{Introduction}

The implementation of the Federal scientific and technical program for agricultural development for 2017-2025, approved by the government of the Russian Federation Resolution No. 996 of August 25, 2017, provides for the development of subroutines for the selection and seed production of a number of agricultural crops. One of the key tasks is the introduction of technologies for cultivation and production of highly productive oilseeds, reducing the level of dependence on foreign analogues [1].

The development of vegetable oil production facilities in Russia and the increased demand in the world's industrial markets encourages the development of domestic competitive technologies for growing, storing and processing sunflower, soybean and rapeseed.

Currently, the share of foreign breeding achievements in Russia is at least $56 \%$ of the sown areas of spring rapeseed, $76 \%$ of winter rapeseed, $74 \%$ of sunflower and $26 \%$ of soy. Thus, oilseeds, especially sunflower and rapeseed, are import-dependent crops. Over the past 10 years, world production of soy and sunflower has increased by 1.6 times, and rapeseed by 1.4 times [2].

\footnotetext{
${ }^{*}$ Corresponding author: buklagin@rosinformagrotech.ru
} 
According to the oilseed market research and forecast published by the international research and consulting firm MarketsandMarkets ${ }^{\mathrm{TM}}$, the global oilseed market is estimated at us $\$ 250.0$ billion in 2019 and is projected to reach US $\$ 335.0$ billion by 2025 . The growth of the oilseed market by an average of $5.0 \%$ during the forecast period will be driven by factors such as the growing demand for protein products and non-GMO oilseeds [3].

The growth of world production of oilseeds is due to the following reasons [4]:

- in developed countries, there is a reorientation of fat consumption from animal to vegetable for both medical and economic reasons;

- growing demand for vegetable oil in the most densely populated regions of the world;

- oilseeds are a source of plant-based dietary protein that is growing in demand all over the world;

- intensification of animal husbandry requires an increase in the share of oilseed meal and cake for the production of concentrates for modern diets;

- increasing demand for oilseeds for biofuel production and other technical needs.

The analysis of foreign research in the field of oilseeds processing has shown that the main research is aimed at using by-products of oilseeds processing- oil cake and meal as an energy source $[5,6]$, the search for alternative uses of organic solvents for oil extraction [7, $8]$, the study of products in the form of protein feeds obtained during oil extraction to replace more expensive feed ingredients [9], the search for technologies for obtaining food products such as polyphenols, isolates and hydrolysates of oil cake proteins, etc. [10].

In addition, due to the fact that most of the rapeseed oil produced in the world is used for technical purposes (biodiesel), environmental aspects of processing are considered as a separate direction of breeding programs. Another important area of selection should be improving the feed quality of the meal by improving its digestibility and taste advantages, as well as obtaining raw materials suitable for deep processing. The creation and introduction of innovative varieties and hybrids of rapeseed with increased added value, for example, with a modified fatty acid composition, more oxy - and thermally stable, forming fewer products with negative properties in terms of the nutritional value of food products and for technical use (bio-lubricants, biofuels) becomes relevant. It is believed that to improve the effectiveness of breeding programs in the next 10-25 years, it is necessary to take into account the needs and requirements of all parts of the supply chain and, especially, the processing industry [11].

All this leads to an increase in the needs of the domestic and global market for oilseeds, an increase in crops, production and export of vegetable oils from the Russian Federation, as well as a corresponding increase in the flow of varieties and production volumes of seeds supplied to the market by breeding institutions. The share of foreign-selected varieties approved for use in the Russian Federation ranges from 29\% for sunflower (soy) to $87 \%$ (winter rape). The purpose of this study is to analyze the current state of domestic production of sunflower, soybean and rapeseed, assess the use of oilseeds of foreign selection, as well as a comparative analysis of the main characteristics of sunflower varieties of domestic and foreign selection based on the results of tests in two regions of the Russian Federation.

\section{Materials and methods}

The method of information and logical analysis of domestic and foreign scientific and technical information, materials of state statistics, the state register of breeding achievements approved for use, as well as characteristics of sunflower varieties tested in two regions of the Russian Federation were used. 


\section{Main results}

Oilseeds in the Russian Federation account for about $15 \%$ of the total acreage, but three oilseeds dominate: sunflower, soy, and rapeseed. All other crops occupy about $10 \%$ of the acreage allocated for oilseeds (tables 1,2) [12].

Table 1. Acreage of oilseeds in the Russian Federation (in farms of all categories), thousand hectares.

\begin{tabular}{|c|c|c|c|c|c|}
\hline Culture & 2014 & 2015 & 2016 & 2017 & 2018 \\
\hline Total & 11211 & 11516 & 12320 & 12630 & 13941 \\
\hline \multicolumn{6}{|l|}{ Including } \\
\hline Sunflower & 6911 & 7012 & 7606 & 7994 & 8160 \\
\hline Soy & 2012 & 2130 & 2237 & 2636 & 2949 \\
\hline Spring rape & 913 & 876 & 881 & 851 & 1386 \\
\hline Winter rape & 276 & 145 & 98 & 154 & 189 \\
\hline Other & 1099 & 1353 & 1498 & 995 & 1257 \\
\hline
\end{tabular}

Table 2. Gross harvest of oilseeds in the Russian Federation in all categories of farms, thousand tons.

\begin{tabular}{|c|c|c|c|c|c|}
\hline Culture & 2014 & 2015 & 2016 & 2017 & 2018 \\
\hline Oilseeds, total & 12870 & 13854 & 16271 & 16497 & 19525 \\
\hline \multicolumn{6}{|l|}{ Including } \\
\hline Sunflower & 8481 & 9289 & 11015 & 10481 & 12756 \\
\hline Soy & 2371 & 2716 & 3143 & 3622 & 4027 \\
\hline Rapeseed & 1336 & 1013 & 1001 & 1510 & 1989 \\
\hline
\end{tabular}

The average annual production of other oilseeds in the Russian Federation is about 1 million tonnes (6.6 \% of total production) [2]. Given the plans for large-scale expansion of oilseeds, competition between producers may escalate, which requires effective competitive technologies for growing oilseeds [13].

According to the oil and Fat Union, Russia can reach an annual production of 35 million tons of oilseeds and provide a large share of their processing within the country [14]. Sunflower oil ranks second in the Russian Federation in terms of exports. in 2017, for the first time, as many products were exported as were actually consumed within the country. At present, Russia's export capabilities are rated quite high, since the competing countries have reached the production limit. Countries such as India and China will increase imports, and Russian exporters, while with small volumes, are already entering these countries.

In Russia, there are about nine million tons of underloaded capacity, so in the next two or three years, you can increase production only by reloading them. Taking this into account, the area under oilseeds can grow from 12 to 19 million hectares by 2024, and the total potential of Russia to accommodate oilseeds is estimated at 33.5 million hectares [15].

Soybean production may increase due to reclamation development programs. If we introduce about 466,000 hectares of reclamation land in Russia by 2024 , we will have 350,000 hectares under soybeans, which will give an additional one and a half hundredweight per hectare of yield on all areas. There is also a significant potential for sunflower oil and meal, and Russia may become the first in the world to export this product. Thus, if the necessary volume of raw materials is available, Russia is able to export 15.7 million tons of products by 2024 .

The huge potential of Russia lies in the field of oilseeds productivity. According to experts in the field of breeding and seed production, sowing substandard seeds reduces the yield by $20-30 \%$ [4]. This is a huge reserve for increasing the production of oilseeds. In Russia, the average yield for oilseeds for 2014-2018 (table 3) was [12]: for sunflower-1.45 $\mathrm{t}$ / ha, for soybean-1.37 t / ha, for spring rape -1.16 , for winter rape-1.94 $\mathrm{t}$ / ha. 
Table 3. The yield of oilseed crops for the years 2014-2018 in all categories of farms, kg/ha.

\begin{tabular}{|c|c|c|c|c|c|}
\hline Culture & $\mathbf{2 0 1 4}$ & $\mathbf{2 0 1 5}$ & $\mathbf{2 0 1 6}$ & $\mathbf{2 0 1 7}$ & $\mathbf{2 0 1 8}$ \\
\hline Sunflower & 13.1 & 14.2 & 15.1 & 14.5 & 16.0 \\
\hline Soy & 12.3 & 13.0 & 14.8 & 14.1 & 14.7 \\
\hline Spring rape & 11.2 & 9.8 & 10.2 & 14.5 & 12.4 \\
\hline Winter rape & 16.8 & 19.3 & 18.2 & 22.7 & 19.8 \\
\hline
\end{tabular}

These data indicate a significant lag in the yield of oilseeds in the Russian Federation from the world level. Thus, the yield of sunflower is 1.6 times lower than the world level, soy is 2 times lower, and rapeseed is 1.3-2 times lower. At the same time, high yields were obtained in regions with significant land resources allocated for sunflower cultivation. For example, in the Krasnodar region, it was recorded at $2.47 \mathrm{t} / \mathrm{ha}$, while the maximum yield of sunflower seeds was obtained in the Bryansk region (experimental varieties), where it reached a value of $3.49 \mathrm{t} / \mathrm{ha}[16]$.

Experts note that the productivity of growing oilseeds is primarily affected by the quality of the seed material, as well as the choice of plant protection products, fertilizers, and the selection of equipment that must meet the characteristics of the region and minimize the cost of cleaning [17]. The increase in acreage under oilseeds, development of capacities on production of vegetable oil in Russia and increased demand for industry world markets accompanied by development of exports and imports of oilseeds and the corresponding increase in the flow of varieties and production of seeds, supply of breeding institutions [18].

The number of oilseed varieties included in the State register in 2014-2019 is characterized by the data given in table 4 [19-24].

Table 4. Number of oilseed varieties included in the State register.

\begin{tabular}{|c|c|c|c|c|c|c|c|}
\hline \multirow[t]{2}{*}{ Year } & \multirow{2}{*}{$\begin{array}{c}\text { Number } \\
\text { of } \\
\text { varieties } \\
\text { of } \\
\text { oilseeds }\end{array}$} & \multicolumn{6}{|c|}{ Including } \\
\hline & & New & Protected & Sunflower & Soy & $\begin{array}{l}\text { Rapeseed } \\
\text { spring }\end{array}$ & $\begin{array}{c}\text { Rapeseed } \\
\text { winter }\end{array}$ \\
\hline 2014 & 1165 & 70 & 342 & 720 & 144 & 99 & 97 \\
\hline 2015 & 1292 & 152 & 381 & 810 & 170 & 110 & 108 \\
\hline 2016 & 1087 & 93 & 363 & 554 & 181 & 115 & 107 \\
\hline 2017 & 1177 & 127 & 379 & 586 & 210 & 123 & 109 \\
\hline 2018 & 1255 & 126 & 434 & 631 & 223 & 130 & 109 \\
\hline 2019 & 1327 & 83 & 477 & 672 & 239 & 140 & 108 \\
\hline
\end{tabular}

These data show that over the past five years, the number of breeding achievements for oilseeds approved for use in the Russian Federation, for sunflower and winter rapeseed does not change significantly, for soybean and spring rapeseed have an upward trend.

In 2019, the State register of oilseed varieties included 1327 names of varieties and hybrids of oilseeds, including sunflower - 672 names (50\%), soy-239 names (18\%), rapeseed-248 names (19\%). The share of foreign-selected varieties approved for use is $59 \%$ for sunflower, $29 \%$ for soybean, $49 \%$ for spring rape, and $87 \%$ for winter rape.

As world experience shows, increasing the yield of oilseeds can be achieved by switching to the cultivation of hybrids. Therefore, foreign breeding institutions promote hybrids, due to a more effective mechanism for returning funds invested in breeding. According to [25], the share of foreign breeding achievements in Russia is not less than 56 $\%$ of the sown areas of spring rapeseed, $76 \%$ of winter rapeseed, $74 \%$ of sunflower and $26 \%$ of soy. Thus, oilseeds, especially sunflower and rapeseed, are import-dependent crops. 
Leaders among foreign companies whose varieties are included in the state register are: for sunflower - EURALIS SEMENCES (France), for soybean - SEMENCES PROGRAIN INC. (Canada), for spring rape NORDDEUTSCHE PFLANZENZUCHT HANS-GEORG LEMBKE KG (Germany), for winter rape - DEUTSCHE SAATVEREDELUNG AG (Germany). Given that the return on funds invested in the creation of hybrids is higher than in varieties, foreign breeding institutions promote the cultivation of hybrids.

The analysis shows that domestic companies that rely heavily on the achievements of foreign science still find it difficult to compete with foreign manufacturers of hybrids, but there is already a positive experience. As an example, the company "Rosagrotrade", which uses best practices in the selection of sunflower and other crops of domestic (Krasnodar research Institute) and French breeders (RAGT Semences, Florimond Desprez), grows seeds, brings them to sowing conditions at its modern plant "Cimbria" in the Krasnodar region, using science-intensive projects. The cost of such products is 2-3 thousand rubles per seeding unit less than that of foreign manufacturers [26].

The dependence of domestic production on seeds of foreign selection is explained by the following reasons:

lack of organizational and economic mechanisms for conducting scientific research in the field of breeding and seed production at the current level;

low level of state support and low interest in investments from business;

outdated material and technical and instrument-analytical base that does not provide the necessary quality of seeds in their preparation, as well as in varietal and seed control.

To assess the effectiveness of varieties and hybrids of oilseeds of domestic and foreign selection, specialists of the Federal state budgetary institution "Gossortkommissiya" annually test new varieties for economic utility. The characteristics of varieties and hybrids obtained as a result of testing are the basis for their inclusion in the State register of breeding achievements approved for use. The number of tested oilseed varieties in 20132017 is shown in table 5 [27-31].

Table 5. Number of tested oilseed varieties in 2013-2017.

\begin{tabular}{|c|c|c|c|c|}
\hline \multirow{2}{*}{ Varieties } & \multirow{2}{*}{ Sunflower } & \multirow{2}{*}{ Soy } & \multicolumn{2}{|c|}{ Rapeseed } \\
\cline { 4 - 5 } & & & Spring & Winter \\
\hline Domestic & 108 & 61 & 13 & 7 \\
\hline Foreign & 169 & 35 & 35 & 28 \\
\hline
\end{tabular}

To compare the results of tests of sunflower varieties of domestic and foreign selection, the varieties approved for use in the Central black earth (table 6) and North Caucasus (table 7) regions were selected, as well as the following indicators: yield, oil collection, fat content and weight of 1000 seeds.

Table 6. Statistical indicators of sunflower seed quality in the Central black earth region.

\begin{tabular}{|c|c|c|c|c|}
\hline Indicators & $\begin{array}{c}\text { Number of } \\
\text { tested }\end{array}$ & $\begin{array}{c}\text { Varieties } \\
\text { average } \\
\text { arithmetic }\end{array}$ & $\begin{array}{l}\text { Standard } \\
\text { deviation }\end{array}$ & $\begin{array}{l}\text { Deviation range } \\
\text { of changes in the } \\
\text { indicator }\end{array}$ \\
\hline \multirow{4}{*}{ Yield. C / ha } & \multicolumn{4}{|c|}{ Domestic varieties } \\
\hline & 54 & 28.3 & 3.2 & $21.7-34.9$ \\
\hline & \multicolumn{4}{|c|}{ Foreign varieties } \\
\hline & 85 & 32.1 & 2.3 & $27.8-39.4$ \\
\hline \multirow{4}{*}{ Yield of oil. kg/ha } & \multicolumn{4}{|c|}{ Domestic varieties } \\
\hline & 48 & 12.0 & 1.7 & $8.5-16.0$ \\
\hline & \multicolumn{4}{|c|}{ Foreign varieties } \\
\hline & 76 & 13.0 & 2.5 & $8.2-19$ \\
\hline \multirow{2}{*}{$\begin{array}{c}\text { Fat content in seeds. } \\
\%\end{array}$} & \multicolumn{4}{|c|}{ Domestic varieties } \\
\hline & 64 & 48.9 & 2.5 & $43.7-54.7$ \\
\hline
\end{tabular}




\begin{tabular}{|c|c|c|c|c|}
\hline & \multicolumn{4}{|c|}{ Foreign varieties } \\
\hline & 82 & 49.1 & 2.3 & $43.2-54.7$ \\
\hline \multirow{4}{*}{$\begin{array}{l}\text { Weight of } 1000 \\
\text { sunflower seeds. g }\end{array}$} & \multicolumn{4}{|c|}{ Domestic varieties } \\
\hline & 52 & 59.4 & 11.3 & $45.5-109.6$ \\
\hline & \multicolumn{4}{|c|}{ Foreign varieties } \\
\hline & 60 & 58.5 & 7.1 & $45.5-90.4$ \\
\hline
\end{tabular}

Table 7. Statistical indicators of the quality of tested sunflower varieties in the North Caucasus region.

\begin{tabular}{|c|c|c|c|c|}
\hline Indicators & $\begin{array}{c}\text { Number of } \\
\text { tested }\end{array}$ & $\begin{array}{l}\text { Varieties average } \\
\text { arithmetic }\end{array}$ & $\begin{array}{r}\text { Standard } \\
\text { deviation }\end{array}$ & $\begin{array}{c}\text { Deviation } \\
\text { range of } \\
\text { changes in the } \\
\text { indicator }\end{array}$ \\
\hline \multirow{4}{*}{ Yield. C / ha } & \multicolumn{4}{|c|}{ Domestic varieties } \\
\hline & 39 & 21.8 & 2.0 & $19.2-28.2$ \\
\hline & \multicolumn{4}{|c|}{ Foreign varieties } \\
\hline & 26 & 24.2 & 2.3 & $20.3-32.9$ \\
\hline \multirow{4}{*}{ Yield of oil. kg/ha } & \multicolumn{4}{|c|}{ Domestic varieties } \\
\hline & 32 & 11.4 & 1.7 & $8.2-16$ \\
\hline & \multicolumn{4}{|c|}{ Foreign varieties } \\
\hline & 23 & 11.6 & 2.1 & $8.4-16.1$ \\
\hline \multirow{4}{*}{$\begin{array}{l}\text { Fat content in seeds. } \\
\%\end{array}$} & \multicolumn{4}{|c|}{ Domestic varieties } \\
\hline & 46 & 47.8 & 3.1 & $40-55.5$ \\
\hline & \multicolumn{4}{|c|}{ Foreign varieties } \\
\hline & 26 & 48.2 & 2.6 & $43.1-53.5$ \\
\hline \multirow{4}{*}{$\begin{array}{l}\text { Weight of } 1000 \\
\text { sunflower seeds. g }\end{array}$} & \multicolumn{4}{|c|}{ Domestic varieties } \\
\hline & 28 & 60.2 & 11.5 & $49.1-93.4$ \\
\hline & \multicolumn{4}{|c|}{ Foreign varieties } \\
\hline & 20 & 59.7 & 8.3 & $50.7-91.7$ \\
\hline
\end{tabular}

To assess the reliability of the results obtained, we determine the difference between the average performance indicators of the tested sunflower varieties of domestic and foreign selection and the t-criterion according to the formula [32]:

$$
\mathrm{t}=\left(\mathrm{M}_{1}-\mathrm{M}_{2}\right) /\left(\sqrt{ }(\Delta 1)^{2}+(\Delta 2)^{2}\right)
$$

where $M_{1}$ and $M_{2}$ are the average values of the measured indicators, $\Delta_{1}$ and $\Delta_{2}$ measurement errors.

The resulting difference in the definition of indicators is reliable with a probability of 0.95 if $\mathrm{t}>2$ and unreliable if $\mathrm{t}<2$.

A reliable estimate of the difference in the measurement of two indicators is a nontrivial task, since with a decrease in the difference, the relative error in measuring the difference can reach very large values. In this case, the error in measuring the average values of indicators will be determined by two components-the error of the devices used to measure the average performance of varieties, as well as the number of tested varieties, which determines the random component. When determining the reliability criterion $t$, it is assumed that the relative measurement error of the compared indicators $\gamma=2 \%$.

The calculations performed using the given formula (table 8) show that a reliable estimate of the difference in the measured performance indicators of sunflower varieties of domestic and foreign selection, approved for use in the North Caucasus and Central black earth regions, can only be considered when comparing the yield index and oil removal from 1 ha in the Central black earth region. For indicators of oil collection in the North Caucasus region, the fat content in seeds and the weight of 1000 seeds, it is not possible to say with a high probability that foreign varieties are better than domestic ones, or domestic ones are 
better than foreign ones. In this case, the difference in average values between domestic and foreign varieties can be considered insignificant.

Table 8. Reliability of estimation of the difference in performance indicators of the tested sunflower varieties.

\begin{tabular}{|l|c|c|c|c|c|c|}
\hline \multirow{2}{*}{ Indicators } & \multicolumn{2}{|c|}{ Central black earth region } & \multicolumn{3}{c|}{ North Caucasus region } \\
\cline { 2 - 7 } & $\begin{array}{c}\text { Difference } \\
\text { of } \\
\text { measured } \\
\text { values }\end{array}$ & $\begin{array}{c}\text { t- } \\
\text { criterion }\end{array}$ & $\begin{array}{c}\text { Reliability } \\
\text { of the } \\
\text { estimate at } \\
\gamma=\mathbf{0 . 0 2}\end{array}$ & $\begin{array}{c}\text { Difference } \\
\text { of } \\
\text { measured } \\
\text { values }\end{array}$ & $\begin{array}{c}\text { Reliability } \\
\text { of the } \\
\text { criterion } \\
\text { estimate at } \\
\gamma=\mathbf{0 . 0 2}\end{array}$ \\
\hline $\begin{array}{l}\text { Yield. C / } \\
\text { ha }\end{array}$ & $3.8^{*}$ & 4.5 & reliable & $2.4^{*}$ & 3.64 & reliable \\
\hline $\begin{array}{l}\text { Yield of } \\
\text { oil }\end{array}$ & $1.0^{*}$ & 2.8 & reliable & $0.2^{*}$ & 0.58 & unreliable \\
\hline $\begin{array}{l}\text { Fat } \\
\text { content in } \\
\text { seeds. \% }\end{array}$ & $0.2^{*}$ & 0.9 & unreliable a & $0.4^{*}$ & 0.3 & unreliable \\
\hline $\begin{array}{l}\text { Weight of } \\
\begin{array}{l}1000 \\
\text { sunflower } \\
\text { seeds. g }\end{array}\end{array}$ & 0.9 & 0.5 & unreliable & 0.5 & 0.3 & unreliable \\
\hline
\end{tabular}

*- the foreign variety has a higher index.

\section{Conclusions}

The analysis showed that at present the share of oilseeds in Russia of foreign selection allowed for use is $59 \%$ for sunflower, $87 \%$ for winter rapeseed, and $49 \%$ for spring rapeseed. for soy-29\%. This dependence of the Russian agricultural market on foreign seed suppliers creates certain risks for the sustainable production of oilseeds. At the same time, as shown in the examples considered, the advantage and wide use of varieties of foreign selection may not be sufficiently justified.

To improve the reliability of determining seed quality indicators, evaluating the advantages of domestic or foreign varieties and making a decision on their use, it is necessary to improve the laboratory and technological base of domestic seed breeding institutions and centers, and increase the number of tested varieties. This will allow us to apply modern competitive technologies and test methods in the selection and seed production of oilseeds, based on the latest scientific achievements and ensuring the production of original and elite seeds of domestic selection that are not inferior to foreign ones.

In order to reduce the number of ineffective and non-essential advantages of oilseed varieties of foreign selection, only those varieties that have a statistically significant difference between the indicators of varieties of domestic and foreign selection obtained during comparative tests should be included in the State register of selection achievements approved for use.

Since several indicators are used in assessing the quality of oilseed varieties, which may differ from domestic varieties in one direction or another, it is difficult to make an informed decision on including a foreign-selected variety in the State register of breeding achievements when comparing them. In this case, it is necessary to develop an integral indicator of the quality of the variety or use the main indicator that has the highest weight coefficient among the individual quality indicators of the tested varieties for comparison. $b$ 


\section{References}

1. Federal scientific and technical program for agricultural development for 2017-2025 (UTV. Resolution of the Government of the Russian Federation of August 25, 2017 No. 996) (Rosinformagrotech, Moscow, 2017)

2. V.F. Fedorenko, N.P. Mishurov, V.V. Pylnev, D.S. Buklagin, Analysis of the state and prospects of development of selection and seed production of oilseeds: scientific. analyte. Review (Rosinformagrotech, Moscow, 2019)

3. By 2025, the world market of oilseeds will become significantly more expensive, https://fermer.blog/news/mir/10137-k-2025-godu-mirovoy-rynok-maslichnyh-kulturznachitelno-podorozhaet.html

4. D.A. Kerimov, Internet-journal "science of SCIENCE" 6 (2013)

5. Future of the Canadian oilseeds industry, http://canadianfoodbusiness.com/2013/11/07/future-of-the-canadian-oilseeds-industry/

6. M. Kachel, A. Kraszkiewicz, M. Krajewska, Agricultural engineering 20(1), 45-54 (2016)

7. S.P. Jeevan Kumar, S. Rajendra Prasad, Rintu Banerjee, Chem Cent J. 11(9) (2017)

8. T. Bardeau, R. Savoire, M. Cansell, P. Subra-Paternault, Crops and Lipids 22(4), 56-59 (2015)

9. E. Koeleman, All About Feed \& Dairy Global, Processing of selected oilseed byproducts (2019)

10. Sue-Siang The, Alaa El-Din Bekhit, Chemical Processes and Reaction By-products Involved in the Biorefinery Concept of Biofuel Production (Springer, 2019)

11. S.J. Gurinovich, V.V. Rozhkovan, G.J. Obukh, S.I. Moysey, Naukovo-technichny buleten institutu oleynyh Kultury NAAS 18(18), 31-37 (2013)

12. Federal state statistics service, www.gks.ru/wps/wcm/connect/rosstat_main/rosstat/ru/statistics/enterprise/economy/\#

13. Economics of oilseeds, http://svetich.info/publikacii/analitika/yekonomika-maslichnyhkultur.html

14. Expert: the Russian Federation will increase the export of oilseed processing to 15.7 million tons per year, http://rosng.ru/content/ekspert-rf-narastit-eksport-maslichnoypererabotki-do-157-mln-tonn-v-god

15. V.M. Lukomets, S.V. Zelentsov, K.M. Krivoshlykov, Oilseeds. Scientific and technical Bulletin of the all-Russian research Institute of oilseeds 4(164), 81-102 (2015)

16. Sunflower cultivation, https://ekoshka.ru/podsolnechnik-urozhajnost-s-ga/

17. Oilseed business, https://www.agroinvestor.ru/technologies/article/15085-maslichnoedelo/

18. S.V. Goncharov, L.A. Gorlova, Scientific and technical Bulletin of the all-Russian research Institute of oilseeds 2(174), 96-100 (2018)

19. State register of selection achievements approved for use. Plant Varieties (ROSINFORMAGROTECH, Moscow, 2014)

20. State register of selection achievements approved for use. Plant Varieties (ROSINFORMAGROTECH, Moscow, 2015) 
21. State register of selection achievements approved for use. Plant Varieties (ROSINFORMAGROTECH, Moscow, 2016)

22. State register of selection achievements approved for use. Plant Varieties (ROSINFORMAGROTECH, Moscow, 2017)

23. State register of selection achievements approved for use. Plant Varieties (ROSINFORMAGROTECH, Moscow, 2018)

24. State register of selection achievements approved for use. Plant Varieties (ROSINFORMAGROTECH, Moscow, 2019)

25. S.V. Goncharov, L.A. Gorlova, Bulletin of the all-Russian research Institute of oilseeds 1(173), 36-41 (2018)

26. Hybrids and varieties: Russian seed market in 2018, https://rynokapk.ru/articles/plants/gibridy-i-sorta/

27. Characteristics of plant varieties that were first included in the State register of breeding achievements approved for use in 2014 (Rosinformagrotech, Moscow, 2017)

28. Characteristics of plant varieties that were first included in the State register of breeding achievements approved for use in 2014 (Rosinformagrotech, Moscow, 2017)

29. Characteristics of plant varieties that were first included in the State register of breeding achievements approved for use in 2014 (Rosinformagrotech, Moscow, 2016)

30. Characteristics of plant varieties that were first included in the State register of breeding achievements approved for use in 2014 (Rosinformagrotech, Moscow, 2017)

31. Characteristics of plant varieties that were first included in the State register of breeding achievements approved for use in 2014 (Moscow: rosinformagrotech, 2018)

32. Assessment of the reliability of the difference in research results, https://studopedia.org/7-21597.html 